\title{
Investigations on Mass Mortalities among Oreochromis niloticus at Mariotteya Stream, Egypt: Parasitic Infestation and Environmental Pollution Impacts
}

\author{
Nisreen E Mahmoud ${ }^{1 *}$, Mohga FM Badawy² and MM Fahmy ${ }^{1}$ \\ ${ }^{1}$ Department of Parasitology Faculty of Veterinary Medicine, Cairo University, \\ ${ }^{2}$ Department of Veterinary Hygiene and Management, Faculty of Veterinary Medicine, Cairo University, Giza 11221, Egypt
}

\begin{abstract}
The present study was carried out to determine the possible causes of an emergent event of respiratory distress with consequent mass mortalities among Nile fish, Oreochromis niloticus (O. niloticus) at Mariotteya stream, an intrastate tributary of River Nile, Egypt. The area of incident extended from Shabramant till Abouseer city (along 4 $\mathrm{km}$ distance) with the direction of water current. Field visits have recorded thousands of dead large sized fish on both sides of the stream while huge numbers of fish of different size accumulated on the water surface showing typical signs of asphyxia. It was also noted that Mariotteya water body is being subjected to multiple sources of pollution through the dumping of improperly treated organic and inorganic chemical wastes in addition to sewage materials. Results of field and laboratory investigations have revealed that, all the examined 60 fish samples were heavily infested with different types of parasites including zoonotic species: Cichlidogyrus arthracanthus (monogenea), Lamproglena monody and Ergasilus sarsi (Copepod), Myxobolus dermatobia, Chilodonella hexastica, Trichodina truttae, Trichodina fultoni, Cryptosporidium spp. and Balantidium spp. (Protozoa), Acanthosentis tilapae. (Acanthocephala), Clinostomum spp., Euclinostomum spp., Heterophid and Prohemistomatid metacercarae (larval of Trematodes). The physical and chemical examinations of water samples and the analysis of heavy metals concentration indicated marked abnormal water quality parameters and environmental pollution which might be incriminated as a primary stress factor that promoted the invasion of parasites as a secondary stress factor. The study concluded that both factors would have interacted to produce this catastrophic intense case of respiratory distress and mass mortalities. The impact of the recorded parasitic infestation and environmental pollution was briefly discussed.
\end{abstract}

Keywords: Egypt; Oreochromis niloticus; Pollution; Mariotteya

\section{Introduction}

River Nile is the main fresh water resource in Egypt, meeting all demands for drinking water, irrigation and industry [1]. It is also the major source of many aquatic food organisms. Anthropogenic sources play a role in introducing several pollutants into the River Nile either directly or indirectly through different drains. Egyptian drains receive large quantities of untreated or partially treated waste water which in turn discharge into River Nile with the amount exceeds its natural ability to attenuate it. Mariotteya stream (El Moheet drain) is an interstate tributary of River Nile that extends through Giza and October governorates and is such a receiving environment for agricultural, industrial and domestic wastes through Sakkara 7 drainage where AlHawamdia sugar factory and Industrial and sewage treatment plants outlets are dumped. These types of pollutants reported to create both localized and regional problems in nearly every country around the world [2], and in some cases, it has been extensive enough to lead to environmental disasters such as mass mortalities of many aquatic species [3].

Numerous causes of fish mass mortalities in natural water resources were reported in many parts of the world and mostly related to number of environmental problems such as acute toxicity of some pollutants [4] also physico-chemical factors such as low dissolved oxygen, high level of un-ionized ammonia and high concentration of heavy metal could be potential causes [5-7]. Mass mortality might be also attributed to pathogen invasion as potential primary causes among cultured and wild fish population particularly viral [8]; bacterial [9]; fungal [10] and parasitic infection [11].

In Egypt, and as a result of pollution, aquatic ecosystems were subjected to repeated cases of mass mortalities among fish population in the past few year; in 2008, mass mortality was recorded among grouper fish along the Mediterranean coast at Marsa Matrouh area, and in 2009 catastrophic mass mortalities occurred among cultured Tilapia fish in King Mariot at Alexandria province, also in Kanater Edfina at El- Behera province. Another cases of mass mortalities erupted among many species of fish through the period of 2010 and 2012 at different localities along River Nile branches in Dakahlia and Behera provinces $[12,13]$.

In January 2010, a disaster of mass mortality and respiratory distress among fish population has been erupted in Mariotteya stream at Giza province leading to great economic loss , and consequently, The aim of the current study was to estimate the consequences of environmental back ground, and the subsequent invasion of the affected fish with parasites in order to estimate the causes that lead to this catastrophic mass mortality.

*Corresponding author: Nisreen. E. Mahmoud, Department of Parasitology, Faculty of Veterinary Medicine, Cairo University, Egypt, Tel: 20-12-262-51648 E-mail: drnisreene@hotmail.com

Received July 20, 2013; Accepted January 16, 2014; Published January 25, 2014

Citation: Mahmoud NE, Badawy MFM, Fahmy MM (2014) Investigations on Mass Mortalities among Oreochromis niloticus at Mariotteya Stream, Egypt: Parasitic Infestation and Environmental Pollution Impacts. J Aquac Res Development 5: 219 doi:10.4172/2155-9546.1000219

Copyright: (C) 2014 Mahmoud NE, et al. This is an open-access article distributed under the terms of the Creative Commons Attribution License, which permits unrestricted use, distribution, and reproduction in any medium, provided the original author and source are credited. 
Citation: Mahmoud NE, Badawy MFM, Fahmy MM (2014) Investigations on Mass Mortalities among Oreochromis niloticus at Mariotteya Stream, Egypt: Parasitic Infestation and Environmental Pollution Impacts. J Aquac Res Development 5: 219 doi:10.4172/2155-9546.1000219

\section{Materials and Methods}

\section{Field visit}

On the $4^{\text {th }}$ of January 2010, the Egyptian media announced a catastrophic mass mortalities among fish in Mariotteya water stream and denoted that, several thousands of fish were lost. An emergent visit to the location of incident was performed by the investigation team for reporting the case history and recording the mortality patterns, the abnormal behavioural change and clinical finding among the affected fish species and also for sampling in order to estimate the potential causes of this mass mortality problem.

\section{Water samples}

Five points along the affected area representing the outlet of Al-Hawamdea sugar factory (site 1), the drainage of industrial and sewage treatment plants (site 2), the outlet of the drainage Sakara 7 to the Mariotteya water stream (site 3). Mariotteya water stream at Shubramant, north to the drainage Sakara 7 (site 4), and Mariotteya water stream south to the drainage Sakara 7 (site 5). (Figures 1-5, Map 1).

Pre-cleaned polyethylene sampling bottles ( 1.5 liter capacity) were immersed about $50 \mathrm{~cm}$ below the water surface, $500 \mathrm{ml}$ of water were taken at each sampling site and acidified on spot with $10 \%$ nitric acid then transported immediately to the laboratory in an ice bath and prepared for analysis as described by APHA, 1998. The water samples were physically examined for colour and temperature $\left({ }^{\circ} \mathrm{C}\right)$ which are measured by a dry mercury thermometer. For Chemical parameters, hydrogen ion concentration was measured by Orion Research Ion Analyser 399A PH meter, dissolved oxygen (DO) was measured using

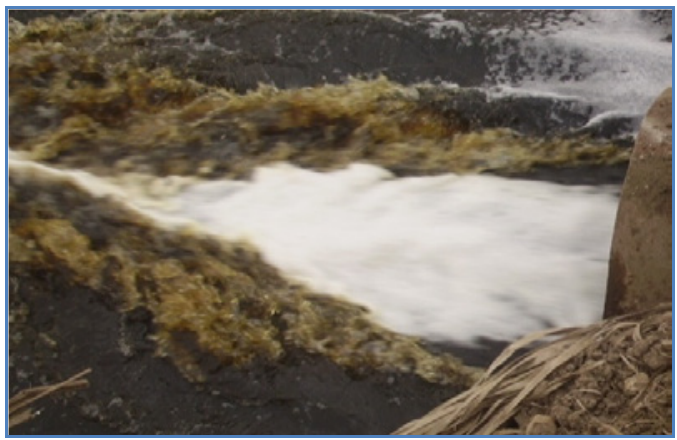

Figure 1: Al-Hawamdeya outlet (Site 1)

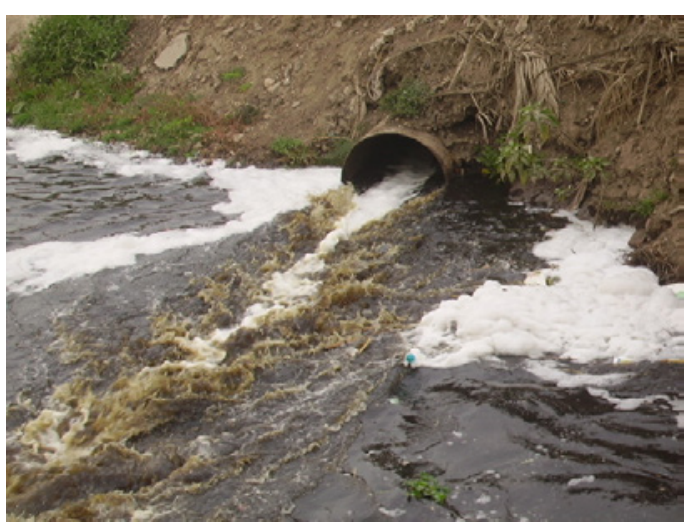

Figure 2: Drainage of sewage treatment plants (Site 2).

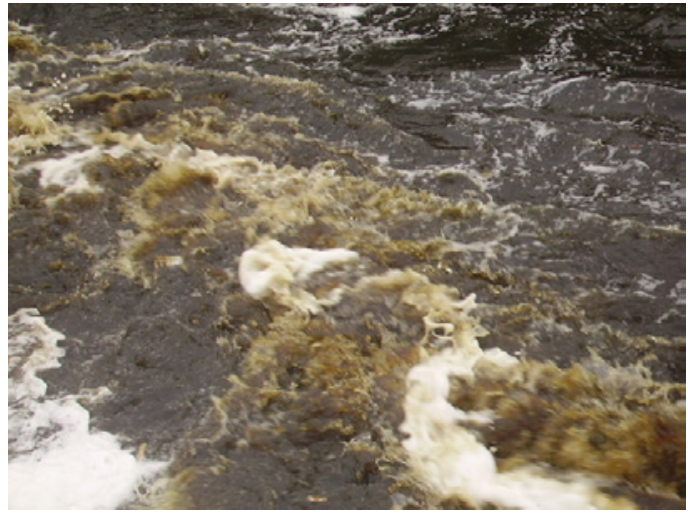

Figure 3: The outlet of the drainage Sakara 7 to Mariotteya water stream (Site 3).

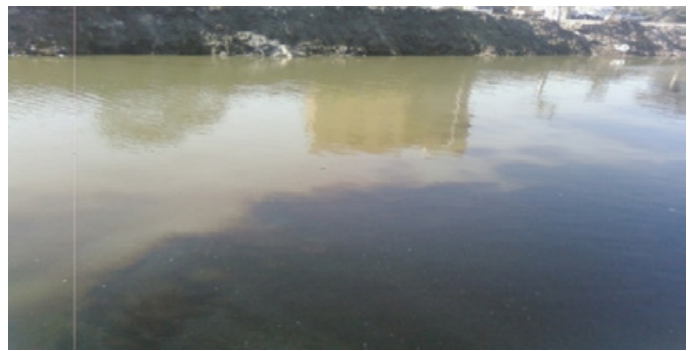

Figure 4: Mariotteya water stream north to Sakara 7 (Site 4).

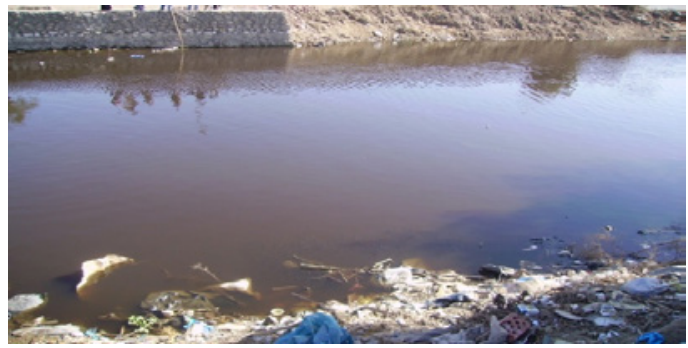

Figure 5: Mariotteya water stream south to Sakara 7 (site 5).

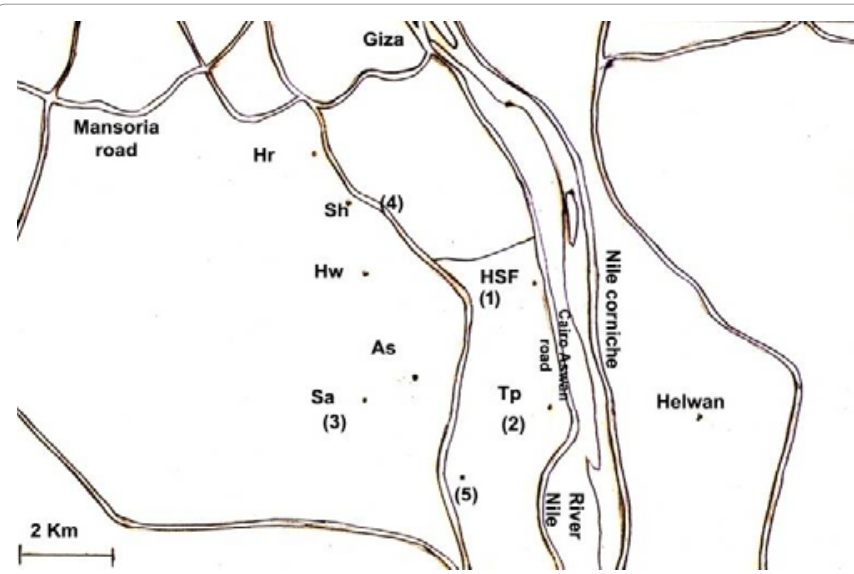

Map 1: Hr: Haram area Sh: Shabramant. Hw: Hawamdia. As: Aboseer. Sa: Sakara 7.

HSF: Hawamdia Sugar Factory. Tp: Treatment plant. 1,2,3,4 and5: Sampling sites.

$\mathrm{N}$ : North direction. 
Citation: Mahmoud NE, Badawy MFM, Fahmy MM (2014) Investigations on Mass Mortalities among Oreochromis niloticus at Mariotteya Stream, Egypt: Parasitic Infestation and Environmental Pollution Impacts. J Aquac Res Development 5: 219 doi:10.4172/2155-9546.1000219

the five days incubation method, and the concentration of ammonia was determined by using the colorimetric techniques according to APHA (1989). Heavy metals; Copper (Cu), Cadmium (Cd) and Lead $(\mathrm{Pb})$ in water samples were determined using atomic absorption spectrophotometer (Model 3100, Perkin-Elma, Norwalk, Conn, USA) according to standard methods described by APHA, 1995. Depending on data during field visit, the water samples were tested for Phenol and Polycyclic aromatic hydrocarbons (PAHs) using High Performance Liquid Chromatography (HPLC, Jasco, Model UV-2076 plus) according to James et al. [14-16].

\section{Fish samples}

A total of 60 O. niloticus (average weight 50-100 g) showing typical signs of asphyxia manifested by gasping, rapid opercular movement were collected from the affected Mariotteya stream water and were transported alive to the laboratory of Parasitology department, Faculty of Veterinary Medicine, Cairo University. The fish were kept in aerated glass aquaria at $25^{\circ} \mathrm{C}$ and subjected to parasitological examination.

\section{Parasitological examination}

Fish samples were examined macroscopically and microscopically for parasites infection. For ectoparasite examination, mucous was scraped with spatula from skin surface, fins, and oral cavity. Samples were examined with fresh preparation method. Fixed preparations were created from the preparation in which parasites were detected. For endoparasite examination, body cavity, muscles and internal organs (livers, spleens, stomach, gall bladder, heart, brain and intestine contents) were examined. Samples were separated according to their species. All the isolated parasites were prepared for permanent mounting followed the standard protocol after Prichard and Krusee [17] and identified according to the guidelines of Lom \& Dykova [18], Kabata [19], Paperna [20], and Yamaguti [21]. Prevalence of the detected parasites were calculated according to Bush et al [22].

\section{Statistical analysis}

Data were presented as Mean \pm standard deviation for numerical variables. To compare mean between groups, student's t test was used. The Statistical analysis was performed using SPSS@ version 16.

\section{Results}

\section{Field visits}

The emergent visit to the site of incident revealed that, fish mortalities were confined to the area extended from Shabramant till Abouseer (distance of about $4 \mathrm{~km}$ ). Thousands of dead and dying large sized Oreochromis niloticus (200-250 g) was recorded along both sides of Mariottya stream. Huge numbers of small sized (50-100 g) were aggregated on the water surface with typical signs of asphixia manifested by gasping and rapid opercular movement. Tanked cars and large numbers of pipes were seen dumping huge quantities of sewage collected from houses into the water stream in addition to the large quantities of garbage accumulated on both sides of Mariotteya water. The mortality and signs of respiratory distress were not detected among fish in mariotteya stream south to sakara 7 . The case history revealed that, the same case of mass mortalities was previously occurred 3 years ago but in limited scale also refers to the role of Alhawamdia sugar factory in polluting Mariotteya stream by pouring it's industrial effluents to the water through Sakara 7 drainage (Figures 6-10)

\section{Water sample examination}

Pysico-chemical parameters: Table 1 shows the mean values of

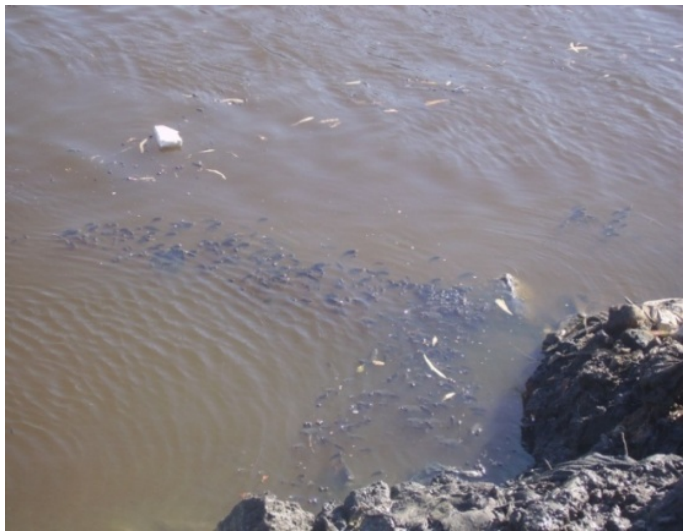

Figure 6: Thousands of dead and dying fish along Mariotteya stream.

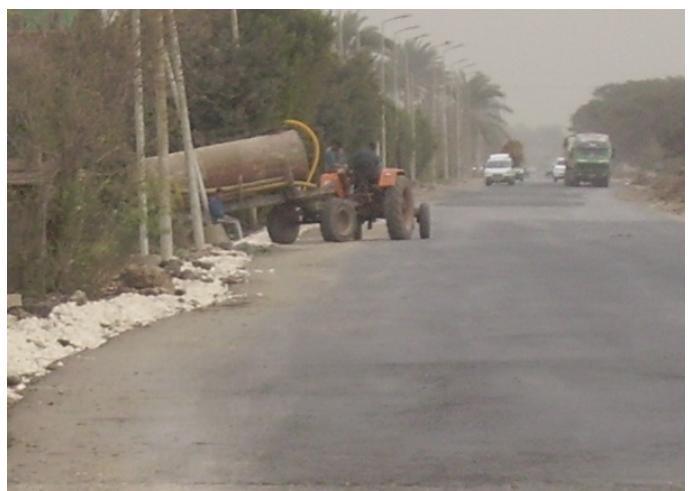

Figure 7: Tanked car dumping sewage material into Mariotteya stream.

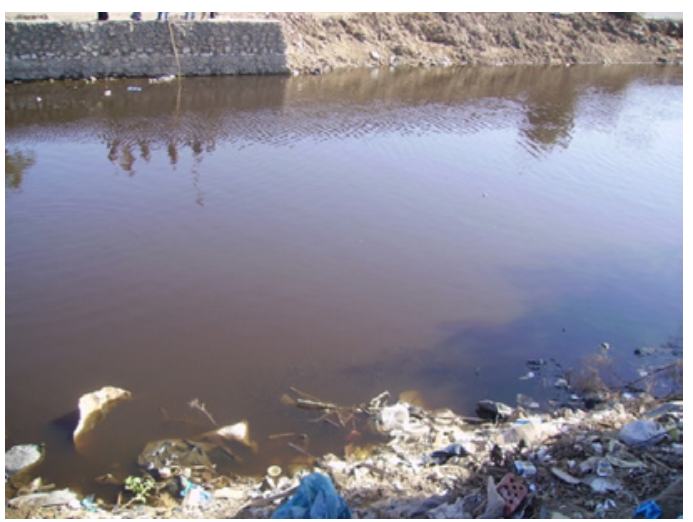

Figure 8: Large quantities of garbage accumulated on both sides of Mariotteya water.

physicochemical parameters of the sampling sites along Mariotteya stream. It is obvious that, the mean values of the different parameters of water in sites $1,2,3$, and 4 were very high with the exception of temperature and $\mathrm{PH}$ while the parameters at site 5 South to Sakara 7 were within the permissible limits except for PAHs. The result also showed depletion in oxygen content in all sampling sites.

Heavy metals: Data reported in table 2 showed the values of the detected heavy metals from different sites along Mariotteya strem and indicated that lead is the most abundant element in Mariotteya stream followed by cadmium. 
Citation: Mahmoud NE, Badawy MFM, Fahmy MM (2014) Investigations on Mass Mortalities among Oreochromis niloticus at Mariotteya Stream, Egypt: Parasitic Infestation and Environmental Pollution Impacts. J Aquac Res Development 5: 219 doi:10.4172/2155-9546.1000219

Page 4 of 7

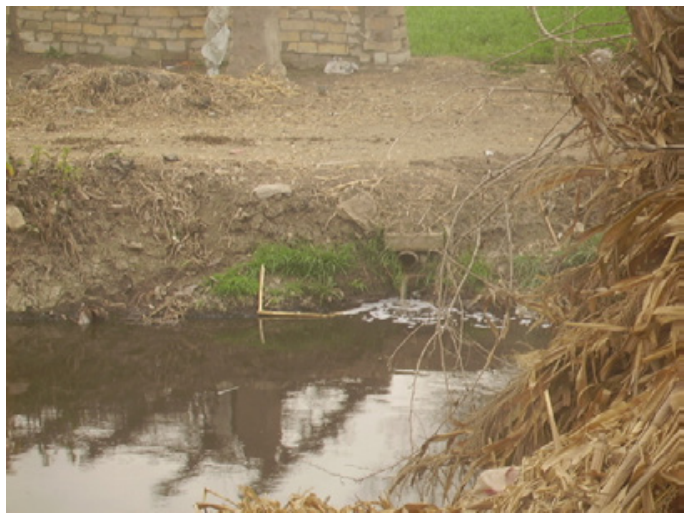

Figure 9: Pipes dumping wastes from houses into Mariotteya water sream.

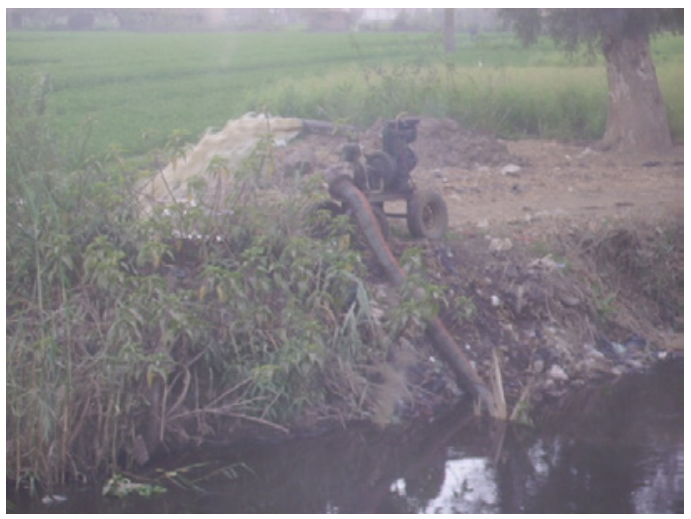

Figure 10: The polluted water is used in irrigation.

\section{Parasitological examination of fish samples}

All the examined fish samples were found parasitized (100\%) with different species of parasites belonging to Trematodes (Monogenea and Digenean metacercarae), Protozoa and Copepods. Protozoan species showed higher prevalence among the examined fish (Tables 3 and 4). Macroscopic examination revealed presence of skin nodules of Myxobolus spp. (Figure 11) and large numbers of Clinostomum spp. metacercarae in the branchial cavities of the examined O. niloticus fish (Figure 12).

\section{Discussion}

In the present investigation, data of field visit revealed that the mass mortalities and signs of respiratory distress among $O$. niloticus were restricted only along the distance of about $4 \mathrm{~km}$ starting from the outlet of Sakara 7 drainage into mariotteya stream at Abuseer at the south and extend to Shabramant at the North with the direction of water current. This restricted area indicated the role of Sakara 7 as source of pollution by receiving the discharge of different sources of pollutants including Al-Hawamdea sugar factory and Industrial and sewage treatment plants.

Results of water analysis revealed that, Mariotteya stream was subjected to high levels of pollutants that introduced to its water through improperly treated industrial, agricultural and sewage wastes. Among the marked abnormal water quality that was detected in the present study, the increase in un-ionized form of ammonia level (reached $55 \mathrm{mg} / \mathrm{L}$ ). According to Elghobashy et al. [23] the high un-ionized ammonia level is an indicator of the presence of sewage discharge, agriculture-runoff and industrial effluents and it might be also attributed to the increase in oxygen consumption of the decomposing organic matter and oxidation of chemical constituents. Toxicty due to un-ionized form of ammonia may predispose to asphyxia and mortalities as it is easily spread through the gills causing behavioural, physiological and histological changes [5]. In addition, Prolonged exposure to concentration of un-ionized ammonia higher than $1 \mathrm{mg} / \mathrm{L}$ causes losses especially among fries and juveniles in water with low dissolved oxygen [24,25].

The reduction in dissolved oxygen content in Mariotteya water samples may be due to decomposition of suspended organic matter of sewage [26]. According to Adeogun, 2012, prolonged exposure of fish to low dissolved oxygen level $(>5 \mathrm{mg} / \mathrm{L}$ ) has direct consequences for the survival of fish and other aquatic animals as DO reduction elicit physiological regulatory mechanisms involved in the maintenance of oxygen gradient from water to tissues which is essential to maintain the metabolic aerobic pathways. Also low DO concentration leads to an increase of organic matter in the water system and considered as a factor that predisposing fish diseases carried by pathogens in water [27].

Al-Hawamdea sugar factoy was incriminated as the main source of the detected phenol which were mostly detected in sugar factories as an end products of hydrolysis of molasses [28,29]. Phenol toxic action is due to its effect on the nervous system also has the same toxic effect of ammonia on fish respiratory function resulting in asphyxia [29].

Poly cyclic aromatic hydrocarbons are the most widespread organic pollutants that known to be carcinogenic and have damaged effects on epithelial tissues of fish body [30]. The detected high level PAHs in Mariotteya water samples $(2.56 \mathrm{mg} / \mathrm{L})$ might be resulted from throwing the untreated industrial wastes of many factories located along the Mariotteya road.

Concerning heavy metals, data of analysis revealed that, $\mathrm{Cu}$ level in Mariotteya water were within the permissible limits indicted by E.O.S (1993) and Egyptian Governmental Low No. 48, 1982., while Cd and $\mathrm{Pb}$ levels were higher than the permissible limit $[31,32]$. Kock and Hofer $[33,34]$ reported that even low concentration of heavy metals in the water may results in high concentration of them in fish flesh the point which is of great concern regarding to fish health directly and human health indirectly. Prolonged exposure of fish to heavy metals causes several histopathological changes especially in the fish gills [35-37] and since gills are the respiratory and osmo-regulatory organ of fish, these histopathological changes might impair the gill respiratory function by reducing respiratory surface area resulted in hypoxia, respiratory failure problems [38-40] which may lead to fish death [41].

Results of water analysis of the five sampled sites, revealed low quality and detection of multiple types of pollutants Sakara 7 showed the worst results, that is might be attributed to the excessive shooting levels of different types of pollutants particularly through Sakara 7 drainage especially with the marked low water column and the stagnant nature of the drainage during that time period of the year (January). On the other side, results indicated that site 5 showed lower level of pollution this is could be due to the flow direction of water current which diluted and so decreased the concentration of pollutants along the stream.

It coud be concluded that the recorded low quality with the detection of multiple pollutants may contribute to the respiratory 
Citation: Mahmoud NE, Badawy MFM, Fahmy MM (2014) Investigations on Mass Mortalities among Oreochromis niloticus at Mariotteya Stream, Egypt: Parasitic Infestation and Environmental Pollution Impacts. J Aquac Res Development 5: 219 doi:10.4172/2155-9546.1000219

Page 5 of 7

\begin{tabular}{|c|c|c|c|c|c|c|c|}
\hline $\begin{array}{l}\text { Site } \\
\text { No }\end{array}$ & Color & $\begin{array}{l}\text { Temp } \\
{ }^{\circ} \mathrm{C}\end{array}$ & $\mathrm{PH}$ & $\begin{array}{c}\text { Ammonia } \\
\mathrm{mg} / \mathrm{L}\end{array}$ & $\begin{array}{c}\mathrm{DO} \\
\mathrm{mg} / \mathrm{L}\end{array}$ & $\begin{array}{c}\text { Phenol } \\
\mathrm{mg} / \mathrm{L}\end{array}$ & $\begin{array}{l}\text { PAHs } \\
\mathrm{mg} / \mathrm{L}\end{array}$ \\
\hline 1 & Redish brown with foams & 21.3 & 8.7 & 17 & 3.5 & 5.0 & 60.8 \\
\hline 2 & Redish brown with foams & 22 & 8.2 & 15.5 & 3.5 & 1.5 & 4.3 \\
\hline 3 & Dark brown & 20.7 & 8.6 & 55 & 3 & 4.5 & 25.7 \\
\hline 4 & Redish brown & 20 & 8.4 & 10.5 & 4 & 1.8 & 13.3 \\
\hline 5 & Yellowish & 21 & 7.5 & 0.02 & 4.5 & 0.0 & 8.5 \\
\hline Mean \pm SD & & $21 \pm 0.73$ & $8.28 \pm 0.47$ & $19.60^{\star *} \pm 0.87$ & $3.70 \pm 0.57$ & $2.56^{* *} \pm 0.11$ & $22.52^{* *} \pm 0.85$ \\
\hline P.I & & Over 5 & $6.5-9$ & 0.5 & $>5$ & $(-)$ & $(-)$ \\
\hline
\end{tabular}

P.I=Permissible limits **Higher than P.I

Table 1: Physicochemical parameters of the collected water samples from Mariotteya stream.

\begin{tabular}{|l|c|c|c|}
\hline $\begin{array}{l}\text { Site } \\
\text { No }\end{array}$ & $\begin{array}{c}\mathbf{C u} \\
\mathbf{m g} / \mathbf{L}\end{array}$ & $\begin{array}{c}\mathbf{C d} \\
\mathbf{m g} / \mathbf{L}\end{array}$ & $\begin{array}{c}\mathbf{P b} \\
\mathbf{m g} / \mathbf{L}\end{array}$ \\
\hline $1-$ & 0.0399 & 0.060 & 0.830 \\
\hline 2 & 0.050 & 0.050 & 0.300 \\
\hline 3 & 0.035 & 0.045 & 0.0 \\
\hline 4 & 0.034 & 0.140 & 0.650 \\
\hline 5 & 0.00 & 0.162 & 0.435 \\
\hline Mean \pm SD & $0.031 \pm 0.01$ & $0.091^{* *} \pm 0.05$ & $0.443^{* *} \pm 0.31$ \\
\hline P.I & 1.00 & 0.01 & 0.05 \\
\hline
\end{tabular}

P.I=Permissible limits **Higher than P.I

Table 2: Concentrations of heavy metals in the collected water samples from Mariotteya stream.

\begin{tabular}{|c|c|c|c|c|c|c|c|c|}
\hline \multirow{2}{*}{$\begin{array}{l}\text { Examined } \\
\text { number }\end{array}$} & \multirow{2}{*}{$\begin{array}{l}\text { Infected } \\
\text { number }\end{array}$} & \multirow{2}{*}{$\begin{array}{l}\text { Infection } \\
\text { rate }\end{array}$} & \multicolumn{2}{|c|}{ Protozoa } & \multicolumn{2}{|c|}{ Crustacea } & \multicolumn{2}{|c|}{ Helminthes } \\
\hline & & & Number & $\%$ & Number & $\%$ & Number & $\%$ \\
\hline 60 & 60 & 100 & 42 & $70^{*}$ & 37 & 61.66 & 27 & 45 \\
\hline
\end{tabular}

Table 3: Prevalence of parasitic infection.

\begin{tabular}{|c|c|c|c|}
\hline Parasites & $\begin{array}{l}\text { Site of } \\
\text { Infection }\end{array}$ & $\begin{array}{l}\text { Number of } \\
\text { infected } \\
\text { fish }\end{array}$ & $\begin{array}{l}\text { Prevalence } \\
\%\end{array}$ \\
\hline \multicolumn{4}{|l|}{ Monogenea: } \\
\hline Cichlidogyrus arthracanthus & Gills & 25 & 41.67 \\
\hline \multicolumn{4}{|l|}{ Digenea (metacercarae): } \\
\hline Clinostomum sp. metacercarae & Branchial cavities & 19 & 31.66 \\
\hline Euclinostomum sp. metacercarae & Branchial cavities & 3 & 5.0 \\
\hline Heterophid sp. metacercarae & Muscles and skin & 21 & 35.0 \\
\hline Prohemistomid sp. metecercarae & Muscles & 20 & 33.33 \\
\hline \multicolumn{4}{|c|}{ Acanthocephala: } \\
\hline Acanthosentis tilapea. & Intestine & 11 & 55.0 \\
\hline \multicolumn{4}{|l|}{ Protozoa: } \\
\hline Chilodonella sp. & Skin & 12 & 20.0 \\
\hline \multicolumn{4}{|l|}{ Trichodina truttae. } \\
\hline Trichodinafultoni & Skin and gills & 32 & 53.33 \\
\hline Balantidium sp. & Intestine & 10 & 16.67 \\
\hline Myxobolus dermatobia. & Skin and eyes & 13 & 21.67 \\
\hline Cryptosporidium sp. & Intestine & 24 & 40.0 \\
\hline \multicolumn{4}{|l|}{ Copepodes: } \\
\hline Lambrogena monody & Gills & 27 & 45.00 \\
\hline Ergasilus sarsi & Gills & 16 & 26.67 \\
\hline
\end{tabular}

Table 4: Prevalence and site of infection of isolated parasite species.

distress and mass mortalities event among O. niloticus in Mariotteya stream.

Parasitic species can be found on every living organisms, their presence in their hosts is generally at equilibrium in aquatic ecosystem [42]. When natural or anthropogenic changes either environmental such as temperature, climate, or anthropogenic such as pollution and urbanization occur it can change the state of balance of the parasite between host and nature, thus resulting in disease or mortality in fish

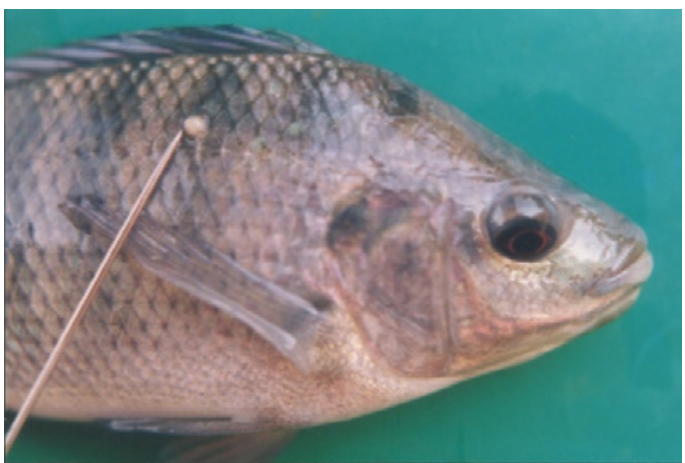

Figure 11: Nodule of Myxobolus dermatobia in skin.

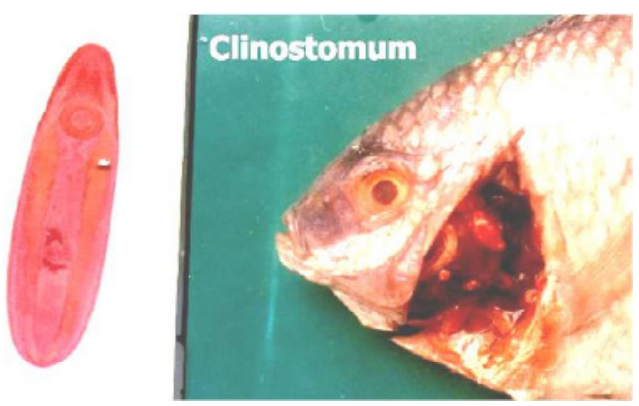

Figure 12: Clinostomum spp metacercarae in branchial cavity.

population. Parasites can cause mechanical damage (fusion of gill lamellae, tissue replacement), physiological damage (cell proliferation, immunomodulation, detrimental behavioral responses, alteration of growth) and also reproductive damage [43]. In addition, zoonotic parasites have considerable human hazard impacts resulted in pathological lesions and diseases $[44,45]$.

Regarding parasitic infestation, results revealed that all (100\%) of the examined $O$. niloticus sampled from Mariotteya stream were heavly infested with different species of parasites, the result which might be attributed to that Heavy pollution increases the susceptibility of the exposed fish to parasitic infection [46] and also causes biochemical and behavioural changes of the host that can influence the prevalence of parasitism by impairing the host's immune responses [47]. These data could support the present record concerning the high prevalence of parasitic infestation (100\%) among the examined O. niloticus sampled from Mariotteya stream. It is important to mention that the detected ectoparasite species including protozoan and crustacean were recorded to cause severe pathological changes and tissue damages in the affected hosts [48] also to keep consideration, the zoonotic importance of the isolated heterophiid and prohemistomatid metacercariae . 
Citation: Mahmoud NE, Badawy MFM, Fahmy MM (2014) Investigations on Mass Mortalities among Oreochromis niloticus at Mariotteya Stream, Egypt: Parasitic Infestation and Environmental Pollution Impacts. J Aquac Res Development 5: 219 doi:10.4172/2155-9546.1000219

Page 6 of 7

In the present investigation, it could be concluded that mass mortalities and asphyxia among $O$. niloticus population along Mariotteya stream might be attributes to multi-factorial synergism of environmental chemical and biological pollution. Depending on data of field visit and results of investigations it could be concluded that the synergism of the marked abnormal water quality and environmental pollution that was indicated by the high levels of Un-ionized ammonia, phenol, PAHCs and heavy metals, sever reduction of DO, in addition to the deleterious impacts of the high prevalence of parasitic infection could constitute a complex problem that might lead to the eruption of this catastrophic event of mass mortalities and respiratory distress among O. niloticus at Mariotteya stream on $4^{\text {th }}$ of January 2010. Releasing new water into Mariotteya stream through other adjacent tributaries of River Nile for three successive days lead to gradual correction of the condition and consequently cessation of signs of asphyxia and mortalities.

\section{Acknowledgment}

The authors thank Dr. Eva Sharaby, researcher at the Egyptian Central Laboratories of the Ministry of Health for the logistic support in field work.

\section{References}

1. Mohamed MAM, Osman MA, Potter TL, Levin RE (1998) Lead and Cadmium in Nile River Water and Finished Drinking Water in Greater Cairo, Egypt. Environment International 24: 767-772.

2. Adeogun AO, Chukwuka AV, Ibor OR (2011) Impact of Abattoir and Saw-Mil Effluent on Water Quality of Upper Ogun River (Abeokuta). American Journal of Environmental Sciences 7: 525-530.

3. Adeogun AO (2012) Impact of Industrial Effluent on Water Quality and Gill Pathology of Clarias Gariepinus from Alaro Stream Ibadan, Southwest, Nigeria. Europian Journal of Scientific Research 76: 83-94.

4. Swako H, Diasuke H, Shin T, Toshiyuki I, Michio K, Hinsuke S (2009) Mass Mortality and Trace Element Residues in Isaza (Gymnogobitus Isaza) Collected from Lake Biwa Japan. Interdisplinary Studies on Environmental ChemistryEnv. Research in Asia Eds, Yobashi and Others 177-183.

5. Grib V, Goncharenko N, Voytyshina D (2006) Saponin as Factor of Mass Fish Mortality in the Rivers of Ukraine. Hydrobiol 4: 61-71.

6. Evans JJ, Pasnik DJ, Brill GG, Kleisius PH (2006) Un-lonized Ammonia Exposure in Nile Tilapia: Toxicity, Stress Response, and Susceptibility to Streptococcus Agalactia. North American Journal of Aquacultural 68: 23-33.

7. Lasheen MR, Abdel-Gawad FKH Alaneny AA, Abd El Bary HMH (2012) Fish as Bio Indicators in Aquatic Environmental Pollution Assessment: A Case Study in Abu-Rawash Area, Egypt. World Applied Sciences Journal 19: 265-275.

8. Herdick RP, Gilad O, Yun S, Spangenberg JV, Marty GD, et al. (2000) A Herpes Virus Associated With Mass Mortality of Juvenile and Adult Koi, A Strain of Common Carp. J Aquatic Animal Health 12: 44-57.

9. Subramanian A, Purushothamann (1985) Mass Mortality of Fish and Invertebrates Associated With a Bloom of Hemidiscus Hardmannianus (Bacillariophyceae) in Parangi-Pettai (South India). Limnology and Oceanography 30: 910-911.

10. Main GF, Gody DT, Lead CA, Yuhara TY, Costa GM, Figueired HC (2009) Aspect of the Natural History and Virulence of $S$. Agalactiae Infection in Nile Tilapia. Veterinary Microbiol 3: 136-180.

11. El Sayed EE, Nisreen Ezz EL Dien and Mahmoud MM (2006) Icthyophthiriasis: Various Fish Susceptibility or Presence of More Than one Strain of The Parasites? Nature and Science 4: 5-13.

12. Amany A, Ismael (2012) Benthic Bloom of Cyanobacteria Associated with Fish Mortality in Alexandria Water. Egyptian Journal of Aquatic Research 38: 241 247.

13. Abou El-Gheit, EN Abdo MH, Mahmoud SA (2012) Impacts of Blooming Phenomenon on Water Quality and Fishes in Quarun Lake, Egypt. International Journal of Environmental Science and Engineering 3: 11-23.

14. APHA (1989) Standard Methods of The Examination of Water and Wastewater American Public Health Association, Washington, DC.
15. APHA (1995) Standard Methods for Examination of Water and Wastewater Analysis. $19^{\text {th }}$ ed. Washington DC: American Public Health Association.

16. APHA (1989) Standard Methods of the Examination of Water and Wastewater in: AE Greenberg, LS Clesceri and AD Eaton (Eds.), APHA, WEF and AWWA $20^{\text {th }}$ Ed, Washington DC, USA 1193

17. Pritchard MH, Kruse GOW (1982) The Collection and Preservation of Animal Parasites. Univ. Nebrasca, Lincoln, London: 144

18. Lom J, Dyková I (1992) Protozoan Parasites of Fishes. Elsevier Science Publishers, Amsterdam 315.

19. Kabata Z (1985) "Parasites and Diseases of Fish Cultured in The Tropics" Taylor and Evanics London and Philladelphia Chapter 10 Injuries Caused by Crustacean Parasites: 121-154.

20. Paperna,I (1996) Parasites Infections and Disease of Fishes in Africa. FAO CIFA Technical Paper No. 31 Food and Agriculture Organization, Rome.

21. Yamaguti S (1963) Parasitic Copepoda and Branchiura of Fishes. Interscience Publishers, New York.

22. Bush AO, Lafferty KD, Lotz JM (1997): Parasitology Meets Ecology on its own Terms. Margolis et al. Revisited. J Parasitol 83: 575-583.

23. Elghobashy HA, Zaghlul KH, Metwally MAA (2001) Effect of Some Wate Pollutants on the Nile Tilapia Oreochromis Niloticus Collected from The River Nile and Some Egyptian Lakes. Egyptian Journal of Aquatic Biology and Fisheries 5: 251-279.

24. Walker MK, Peterson RE (1991) Potencies O Polychlorinated DibenzopDioxin, Dibenzofuran and Biphenyl Congeners, Relative To 2,3,7.8Tetrachlorodibenzo-Dioxin For Producing Early Life Stage Mortality In Rainbow Trout (Oncorhynchus mykiss). Aquatic Toxicolol., 21: 219-238.

25. Harris JO, Greg BM Stephen E, Stephen MH (1998): Effect of Ammonia on The Growth Rate and Oxygen Consumption of Juvenile Greenlip Abalone, Haliotis Laevigata Donovan. Aquaculture 3: 259-272.

26. Tayel SI, Ibrahim SA, Authman MMN, El-Kashef MA (2007) Assessment of Sabal Drainage Canal Water Quality and its Effect on Blood and Spleen Histology of Oreochromis Niloticus. African Journal of Biological Sciences 3 97-107.

27. Suhet MI, Schocken-Itturrino RP (2013) Physical and Chemical Wate Parameters and Streptococcus Species Occurance in Intensive Tilapia Farming in The State of Espirito, Santo, Brazil. Acta Scientiarum. Biological Science Maringa 35: 29-35

28. Klinke HB, Thomsen AB, Ahring BK (2004) Inhibition of Ethanol-Producing Yeast and Bacteria by Degradation Products Produced During Pre-Treatment of Biomass. Appl Microbiol Biotechnol 66: 10-26.

29. Saha NC, Bhunia F, Kaviraj A (1999) Toxicity of Phenol to Fish and Aquatic Ecosystem. Bull Environ Contam Toxcicol 63: 195-202.

30. De Maagd PGJ, Vethaak AD (1998) Biotransformation of Pahs and Thei Carcinogenic Effects in Fish. Nelson. AH(Ed.) The Hand Book of Environmental Chemistry, Part J Pahs and Related Compound 3 Springer. Verlag. Berlin: 265309.

31. Egyptian Governmental Law No 48 (1982) The Implementer Regulations for Law 48/1982 Regarding the Protection of the River Nile and Water Ways From Pollution. Map. Periodical Buul 3-4: 12-35.

32. E.O.S. Egyptian Organization of Standardization (1993): Egyptian Standard, Maximum Level for Heavy Metals Concentration in Food ES. 2360, UDC 546.9: 818 Egypt.

33. Kock G, Hofer R (1998) "Origin of Cadmium and Lead in Clear Soft Water Lake of High- Altitude and High-Latitude, and Their Bioavailability and Toxicity to Fish. J Exs, 86.

34. Olaifa FE, Olaifa AK, Adelaja AA, Owolabi AG (2004) Heavy Meta Contamination of Clarias Gariepinus from a Lake and Fish Farm in Ibadan, Nigeria. African Journal of Biomedical Research 7: 145-148.

35. Mohamed FAES (2003) Histopathological Studies on Some Organs of Oreochromis Niloticus, Tilapia Zilli And Synodontis Schal From El-Salam Canal, Egypt. Egyptian Journal of Aquatic Biology and Fisheries 7: 99-138.

36. Balah AM, El-Bouhy ZM, Easa ME (1993) Histologic and Histopathologic Studies on The Gills of Tilapia Nilotica (Oreochromis Niloticus) Under The Effect of Some Heavy Metals. Zagazig Veterinary Journal 21: 351-364.

37. Rajeshkumar S, Munuswam N (2011) Impact of Metals on Histopathology and 
Citation: Mahmoud NE, Badawy MFM, Fahmy MM (2014) Investigations on Mass Mortalities among Oreochromis niloticus at Mariotteya Stream, Egypt: Parasitic Infestation and Environmental Pollution Impacts. J Aquac Res Development 5: 219 doi:10.4172/2155-9546.1000219

Page 7 of 7

Expression of HSP 70 in Different Tissues of Milk Fish (Chanos Chanos) of Kaattuppalli Island, South East Coast, India. Chemosphere 83: 415-521.

38. Agatha AN (2010) Levels of Some Heavy Metals in Tissues of Bonga Fish, Ethmallosafimbriata from Forcados River. Journal of Applied Environmental and Biological Sciences 1: 44-47.

39. Javed M, Usmani N (2011) Accumulation of Heavy Metals in Fishes: A Human Health Concern. International Journal of Environmental Sciences 2.

40. Yasser AGH, Naser MD ( 2011) Impact of Pollutants on Fish Collected from Different Parts of Shat Al-Arab River: A Histopathological Study. Environmental Monitoring and Assessment 181: 175-182.

41. Abdel-Baki, AS, Dkhil MA, Al-Quraishy S (2011) Bioaccumulation of Some Heavy Metals in Tilapia Fish Relevant to Their Concentration in Water and Sediment of Wadi Hanifa, Saudi Arabia. African Journal of Biotechnology 10: 2541-2547.

42. Marcogliese DJ (2005) Parasites of the Superorganism: Are They Indicators of Ecosystem Health? International Journal of Parasitology 35: 705-716.
43. Lafferty KD, Kuris AM (1999) How Environmental Stress Affects the Impacts of Parasites. Limnology and Oceanography 44: 925-931.

44. Scholz T (1999) Parasites in Cultured and Feral fish. Veterinary Parasitology 84: 317-335

45. Al-Jahdali MO, RM El-S Hassanine (2010) Ovarian Abnormality in a Pathological Case Caused by Myxidium Sp. (Myxozoa, Myxosporea) in One Spotsnapper Fish Lutjanus Monostigma (Teleostei, Lutjanidae) From The Red Sea. Acta Parasitologica 55: 1-7.

46. El-Seify MA, Zaki MS, Abdel, Desouky RY, Hossam H et al. (2011) Study on Clinopathological and Biochemical Changes in Some Freshwater Fishes Infected With External Parasites and Subjected to Heavy Metals Pollution in Egypt. Life Science J 8.

47. Khan RA, Thulin J (1993) Influence of Pollution on Parasites of Aquatic Animals Advances of Parasitology 30: 201-238.

48. Carney SA, Prasch AL, Heideman W, Peterson RE (2006) Understanding Dioxin Developmental Toxicity Using the Zebra Fish Model. Birth Defects Research A 76: 7-18. 